\title{
Cellular Magnesium Level and Magnesium Supplementation in Elite Sports: Effect on Mitochondrial Function (ATP), Lactate-Pyruvate- and Muscle-Metabolism (CK)
}

\author{
Klaus Erpenbach ${ }^{1 *}$, Max C. Erpenbach¹, Wolfgang Mayer², Uwe Hoffmann ${ }^{3}$, Stefan Mücke
}

\author{
${ }^{1}$ Institut für medizinische Leistungsoptimierung und Trainingssteuerung, Marienstraße 1, 50374 Erftstadt, Germany \\ ${ }^{2}$ Lab4more GmbH Bavariahaus, Augustenstraße 10, 80333 München, Germany \\ ${ }^{3}$ Deutsche Sporthochschule Köln, Am Sportpark Müngersdorf 6, 50933 Köln, Germany
}

\begin{abstract}
Received Date: May 20, 2021; Accepted Date: June 04, 2021; Published Date: June 15, 2021
"Coresponding author: Klaus Erpenbach, Institut für medizinische Leistungsoptimierung und Trainingssteuerung, Marienstraße 1, 50374 Erftstadt, Germany. Email: km.erpenbach@t-online.de
\end{abstract}

\section{Abstract}

Muscle injuries and excessive lactate overloads in training or at the end of a season in team sports or at the end of competition preparation in endurance and individual sports are concomitant symptoms in top-level sport, quickly preventing optimal results as well as competition participation. Is whole blood magnesium deficiency responsible for these problems in elite athletes and will magnesium supplementation improve their muscle metabolism or lactate-pyruvate-metabolism?

Methods: In 70 elite athletes [male: 35 - female: 35 / soccer: 19-field hockey: 27 - Olympics: 15 - tennis: 5 - motorsports (DTM-Formula1): 4] whole blood magnesium were determined. In 25 athletes serum and whole blood magnesium, creatine kinase $(\mathrm{CK})$, venous pyruvate and lactate and the mitochondrial energy level ATP were determined before and after 3 months of daily supplementation with $370 \mathrm{mg}$ magnesium and statistically correlated. A Spearman-ranking coefficient of correlation, a chi-quadrat-test by Pearson and an independent t-test were used. $\mathrm{p}<0.05$ was supposed to be significant, $\mathrm{p}<0.01$ highly significant.

Results: In $27.1 \%$ of all elite athletes $(\mathrm{N}=19 / 70)$ a whole blood magnesium deficiency $(\mathrm{vMg}<1.29 \mathrm{mmol} / \mathrm{l})$ was proved. Female athletes were significantly worst supplied than the male athletes [vMg: $1.33 \pm 0.11 \mathrm{mmol} / 1 \mathrm{vs} .1 .41 \pm 0.13 \mathrm{mmol} / \mathrm{l}$ ( $<<0.024]$. Whole blood magnesium $(1.31 \pm 0.15 \mathrm{mmol} / \mathrm{l}$ before vs $1.45 \pm 0.09 \mathrm{mmol} / \mathrm{l}$ after therapy, $\mathrm{p}<0.00025)$, serum magnesium $(0.78 \pm 0.06 \mathrm{mmol} / \mathrm{l}$ before vs $0.93 \pm 0.05 \mathrm{mmol} / \mathrm{l}$ after therapy, $\mathrm{p}<0.00025)$, the venous pyruvate $(0.21 \pm 0.12$ $\mathrm{mg} / \mathrm{dl}$ before vs $0.39 \pm 0.10 \mathrm{mg} / \mathrm{dl}$ after therapy, $\mathrm{p}<0.00025)$ and mitochondrial ATP $(90.56 \pm 10.11 \% \mathrm{~T}$ cells before vs $99.07 \pm 1.21 \% \mathrm{~T}$ cells after therapy, $\mathrm{p}<0.00025)$ significantly increased after 3 month supplementation of $370 \mathrm{mg}$ magnesiumoxide. Venou slactate $(10.62 \pm 3.50 \mathrm{mg} / \mathrm{dl}$ vs. 8,08 $\pm 2.09 \mathrm{mg} / \mathrm{dl}$ after therapy, $\mathrm{p}<0.0025)$, the pyruvate lactate ratio $(69.98 \pm 52.81$ vs. $22.93 \pm 12.29$ after therapy, $\mathrm{p}<0.00025)$ and the creatine kinase CK $(501 \pm 323 \mathrm{U} / \mathrm{l}$ before vs. $294 \pm 161 \mathrm{U} / 1$ after therapy, $\mathrm{p}=0.018$ ) significantly reduced under 3-month of daily magnesium substitution. For each 0.1 $\mathrm{mmol} / \mathrm{l}$ increase in whole blood magnesium, the pyruvate improves significantly by $0.06 \mathrm{mg} / \mathrm{dl}$ and the pyruvate lactate ratio decreases significantly by 90.9 . The improvement of the pyruvate as well as the pyruvate lactate ratio leads to a significant improvement in muscle metabolism (CK) [increase by $0.1 \mathrm{mg} / \mathrm{dl}$ pyruvate decreases $\mathrm{CK}$ by 89.39 , $\mathrm{p}=0.018$, reduction of lactate pyruvate ratio decreases CK by 25.45 . $\mathrm{p}=0.008)$. An absolute risk reduction of $68 \%$ (18/25 before vs $1 / 25$ after therapy) could be calculated for muscular injuries. No side effects were reported.

Conclusion: The determination of serum magnesium in elite sports is not meaningful. Whole blood magnesium (vMg), on the other hand, plays a significant role in the prevention of muscle injuries, independently to the type of sports, by optimizing pyruvate-lactate-metabolism and thus mitochondrial energy production ATP. Further treatment studies have to prove if optimizing whole blood magnesium can lead to an increase in performance.

\section{Introduction}

Micronutrients including vitamins and trace elements are essential. Interacting with each other they are needed daily to maintain all physiological body functions [1-2]. Extensive training with frequent high lactic acidosis, a tight playing schedule, unbalanced or improper diet, frequent travel, and high psychological stress lead to extensive consumption of these micronutrients, resulting in injury in $12.9 \%$ of cases and therefore to training absences and competition cancellations [3-6]. Magnesium is the fourth most abundant mineral in our body and essential for humans. It plays a critical role in health and performance in athletes. Intracellular magnesium functions is a cofactor in over 300 enzyme systems regulating protein synthesis and energy production (Table 1) [7.8]. In addition, it plays an important role in immune defense, oxidative stress regeneration, and pain modulation $[\mathbf{9 , 1 0}]$.

\begin{tabular}{|l|l|}
\hline \multirow{2}{*}{ Protein synthesis: } & Creatine kinase (CK) \\
\cline { 2 - 2 } & Protein kinase \\
\cline { 2 - 2 } Energy metabolism (protein-fat) & Protein cyclase \\
\hline \multirow{2}{*}{$\begin{array}{l}\text { Energy metabolism (carbohydrate) } \\
\text { aerobic: }\end{array}$} & Propionyl-CoA carboxylase \\
\cline { 2 - 2 } & Hexokinase \\
\cline { 2 - 2 } $\begin{array}{l}\text { Energy metabolism (carbohydrate) } \\
\text { anaerobic: }\end{array}$ & Pyruvate kinase \\
\cline { 2 - 2 } & Pyruvate dehydrogenase (PDH) \\
\cline { 2 - 2 } & Lactate dehydrogenase (LDH) \\
\hline
\end{tabular}




\begin{tabular}{|l|l|}
\hline \multirow{4}{*}{ Mitochondrial metabolism: } & Mg-ATP complex V \\
\cline { 2 - 2 } & $\mathrm{Na}+\mathrm{K}^{*}$-ATPase \\
\cline { 2 - 2 } & $\mathrm{Ca}++-\mathrm{ATPa} e$ \\
\cline { 2 - 2 } & H+-ATPase \\
\cline { 2 - 2 } & Pyruvate dehydrogenase (PDH) \\
\hline
\end{tabular}

Table 1: Mg-dependent enzymes for mitochondrial energy production.

Therefore an optimal magnesium status is crucial for constant training and performance (optimal bone-muscleimmune metabolism) in elite athletes. Magnesium is also responsible for maintaining normal muscle contraction and relaxation [11]; optimal magnesium intake can significantly improve this muscle function in athletes [12]. Dietary magnesium controls the conversion of $25(\mathrm{OH}) \mathrm{D} 3$ to its active form, which supports calcium influx and thus bone metabolism. Magnesium deficiency thus correlates negatively with bone metabolism by decreasing osteoblast and increasing osteoclast activity [13-15]. Decreased magnesium intake (below 400mg in men and below $310 \mathrm{mg}$ in women per day) is associated with lower bone density, which counts as a risk factor for stress fractures in competitive athletes [16.17]. In addition, intense anaerobic training or competition leads to increased magnesium loss in sweat and urine, resulting in magnesium deficits in up to $40 \%$ of cases $(8,18,19,26)$. Targeted correction of proven magnesium deficiencies is significantly associated with increased muscular performance and improved cardio-vascular function in athletes [12, 20-22].

However, determination of the blood magnesium status is a challenge, because the serum levels of magnesium do not reflect the current intracellular magnesium supply, since only $1 \%$ of the body magnesium circulates in the serum, but $50 \%$ of the body magnesium is stored in the bone and $49 \%$ intracellular in the muscle and tissue [23, 24]. The determination of magnesium in whole blood is the most meaningful method to determine the exact magnesium status due to the consideration of the intracellular magnesium content and thus to reliably indicate cellular deficits $[\mathbf{2 3}, \mathbf{2 5}]$. The aim of this cohort study $(\mathrm{N}=70)$ is to evaluate the blood magnesium status of top athletes of various sports and in an observational study $(\mathrm{N}=25)$ to correlate the changes in whole blood or serum magnesium status under magnesium supplementation with its impact on mitochondrial and muscle metabolism.

\section{Methods}

70 top athletes exercising different sports (team sports: field hockey and soccer - individual sports: athletics, tennis, motor sports) were included in the cohort study. All participants gave their written consent for data collection.Zellular magnesium in whole blood was examined in all 70 athletes. In addition, 25 elite athletes were substituted with $370 \mathrm{mg}$ magnesium oxide daily for 3 months in an observational study. Serum magnesium, whole blood magnesium, creatine kinase, venous lactate and pyruvate, and cellular ATP were determined before and after supplemenation and calculated in relation to the symptom muscle injury. Using a questionnaire, the frequency of medically confirmed muscle-tendon injuries (muscle-fiber as well as muscle-bundle tears and tendon-muscle tears) was assessed in these 25 competitive athletes.

\section{Magnesium $($ serum $)=$ sMg}

Magnesium in serum was determined using an Abbott Alinity $\mathrm{C}$ automated laboratory instrument according to the manufacturer's instructions (order no. 8P1920).

\section{Whole blood magnesium $($ Na-heparin blood $)=\mathbf{v M g}$}

Magnesium in whole blood was determined by atomic absorption spectrometry (AAS) after acid digestion.

\section{CK (serum)}

Creatine kinase in serum was determined using an Abbott Alinity C automated laboratory analyzer according to manufacturer's instructions (Order No. 8P4220).

\section{Mitochondrial Function by Mitochondrial Membrane Potential (ATP level)}

Peripheral Blood Mononuclear Cell (PBMC) fraction was isolated from heparinized blood by Ficoll density gradient centrifugation and recorded at a concentration of 1 million PBMCs $/ \mathrm{ml}$ in RPMI medium containing 5\% serum. Measurements were performed using the Cell MeterTM JC-10 Mitochondrial Membrane Potential Assay Kit optimized for flow cytometry from ATT Bioquest (Catalog number: 22801) according to the manufacturer's instructions on a FACS Calibur from Becton Dickinson. The dye JC-10. derived and optimized from JC-1. binds selectively in the mitochondrial membrane and changes its fluorescence spectrum from orange to green with decreasing membrane potential. The membrane potential can be considered as a direct summation marker and endpoint for ATP production. As read out, the percentage of T cells (CD3+) without reduction of membrane potential was recorded ("ATP level").

\section{Venous Pyruvate and Lactate}

Lactate was determined from $\mathrm{NaF}$ blood using an Abbott Alinity $\mathrm{C}$ automated laboratory device according to manufacturer's instructions (order no. 8P2120). Pyruvate was also determined photometrically from $\mathrm{NaF}$ blood using a quantitative enzymatic UV kit from Greiner Diagnostic GmbH according to the manufacturer's instructions (order no. 180000). The quotient is calculated from both measured values by dividing the lactate value by the pyruvate value.

\section{Statistical Analysis}

Data were statistically analyzed using IBM®SPSS $®$ software 25. To calculate the correlations between the different parameters, the Pearson correlation coefficient (rP) was used for samples with $n \geq 40$ and no contradiction to the normal distribution in the Kolmogroff-Smirnoff test $(\mathrm{P}>0.1)$. If the conditions were violated, the Spearman correlation coefficient (rSP) was applied. For 2-group mean comparisons, a Levene test was performed to test for variance homogeneity, followed by an independent $\mathrm{T}$ test for homogeneous $(\mathrm{P}>0.1)$ or inhomogeneous variances with two-sided questioning. Results were considered significant for $\mathrm{p} \leq 0.05$ and highly significant for $\mathrm{p} \leq 0.01$. 
Results

\begin{tabular}{|c|c|c|c|c|c|c|c|c|}
\hline & $\begin{array}{l}\text { Total } \\
(\mathbf{N}=70)\end{array}$ & $\begin{array}{l}\text { Female } \\
(\mathrm{N}=35)\end{array}$ & $\begin{array}{c}\text { Male } \\
(\mathrm{N}=35)\end{array}$ & $\begin{array}{l}\text { Soccer } \\
(\mathrm{N}=19)\end{array}$ & $\begin{array}{r}\text { Hockey } \\
(\mathbf{N}=27)\end{array}$ & $\begin{array}{l}\text { Hockey }(\mathbf{O}) \\
(\mathbf{N}=15)\end{array}$ & $\begin{array}{l}\text { Tennis } \\
(\mathrm{N}=5)\end{array}$ & $\begin{array}{c}\text { Motor- } \\
\text { sport } \\
(\mathrm{N}=4)\end{array}$ \\
\hline $\begin{array}{c}\mathrm{vMg} \\
(1.29-1.69 \mathrm{mmol} / \mathrm{l})\end{array}$ & $\begin{array}{c}1.37 \\
\pm 0.15\end{array}$ & $\begin{array}{l}1.33^{*} \\
\pm 0.11\end{array}$ & $\begin{array}{l}1.41^{*} \\
\pm 0.13\end{array}$ & $\begin{array}{c}1.38 \\
\pm 0.15\end{array}$ & $\begin{array}{l}1.35 \\
\pm 0.11\end{array}$ & $\begin{array}{r}1.38 \\
\pm 0.11\end{array}$ & $\begin{array}{l}1.33 \\
\pm 0.06\end{array}$ & $\begin{array}{c}1.54 \\
\pm 0.11\end{array}$ \\
\hline \multicolumn{9}{|c|}{$* \mathbf{p}<\mathbf{0 . 0 2 4}$} \\
\hline
\end{tabular}

Table 2: Whole blood magnesium $(\mathrm{vMg})$ in gender and sports $(\mathrm{N}=70)-\mathrm{O}=$ Olympic athletes.

(Table 2) shows the characteristics of the 70 study participants [male: 35 - female: 35 / soccer: 19 - field hockey: 27, of which Olympic athletes: 15 - tennis: 5 - motor sports (DTM Formula1): 4]. Serum magnesium deficiency was not detected in any athlete, but whole blood magnesium deficiency $(<1.29 \mathrm{mmol} / \mathrm{l})$ was detected in $27.1 \%$ of cases $(\mathrm{N}=19 / 70)$. Female athletes were highly significantly worse supplied with whole blood magnesium $(1.33 \pm 0.11$ vs. $1.41 \pm 0.13 \mathrm{mmol} / \mathrm{l}$, $\mathrm{p}<0.024)$ than their male counterparts. The best supply of whole blood magnesium $(1.54 \pm 0.11 \mathrm{mmol} / \mathrm{l})$ was shown by the motor athletes.

Daily administration of 370mg magnesium oxide (185mg each in the morning and evening) resulted in a highly significant increase in serum magnesium $(0.78 \pm 0.06 \mathrm{mmol} / \mathrm{l}$ before therapy vs $0.93 \pm 0.05 \mathrm{mmol} / \mathrm{l}$ after therapy, $\mathrm{p}<0.00025)$, whole blood magnesium $(1.31 \pm 0.15 \mathrm{mmol} / \mathrm{l}$ before therapy vs $1.45 \pm 0.09 \mathrm{mmol} / \mathrm{l}$ after therapy, $\mathrm{p}<0.00025)$, venous plasma pyruvate $(0.21 \pm 0.12 \mathrm{mg} / \mathrm{dl}$ before therapy vs $0.33 \pm 0.10 \mathrm{mg} / \mathrm{dl}$ after therapy, $\mathrm{p}<0.00025$ ) and cellular ATP $(90.6 \pm 10.1 \%$ T cells before therapy vs 99.1 $\pm 1.2 \% \mathrm{~T}$ cells after therapy, $\mathrm{p}<0.00025$ ) [Figure 1], as well as to a highly significant decrease in venous plasma lactate $(10.62 \pm 3.50 \mathrm{mg} / \mathrm{dl}$ before therapy vs $8.06 \pm 2.09 \mathrm{mg} / \mathrm{dl}$ after therapy, $\mathrm{p}<0.001)$, of lactate-pyruvate quotient $(70 \pm 53$ before therapy vs $23 \pm 12$ after therapy, $\mathrm{p}<0.00025)$ and creatine kinase (CK) $(457.38 \pm 316.06 \mathrm{U} / \mathrm{l}$ before therapy vs $304.50 \pm$ $168.56 \mathrm{U} / \mathrm{l}$ after therapy, $\mathrm{p}<0.036$ ) [Tab. 3 ]. Among these, an absolute risk reduction of $68 \%$ (18/25 before therapy vs $1 / 25$ after therapy) could be calculated for muscle injuries. No side effects (osmotic diarrhea) were complained.

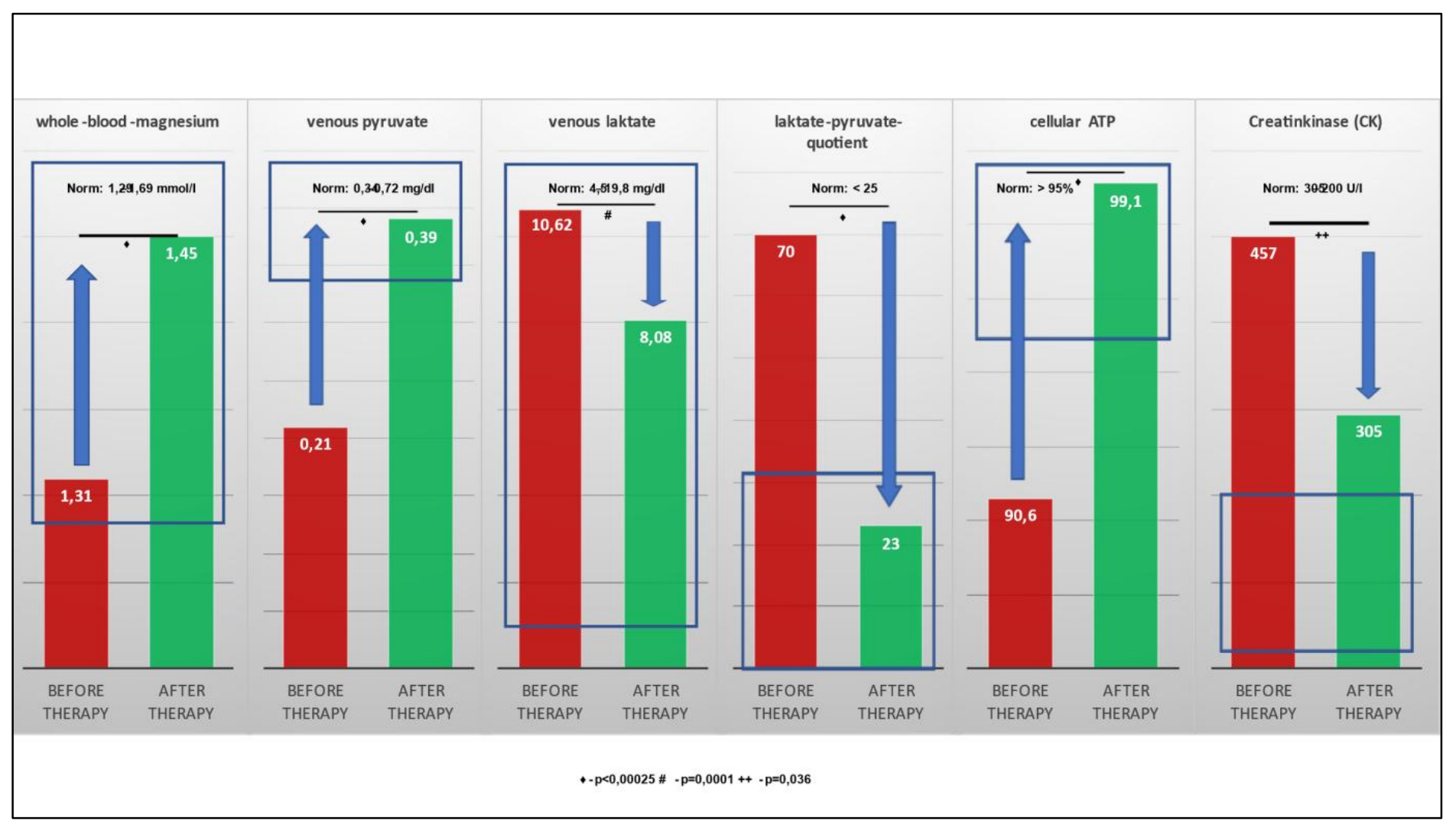

Figure 1: Values before and after 3 months of supplementation with $370 \mathrm{mg}$ magnesium oxide.

The athlete, who experienced a muscle-tendon injury after 3 months despite daily magnesium supplementation, tore the anterior cruciate ligament without external influence.

The significant improvement of whole blood magnesium by daily magnesium supplementation over 3 months resulted in a highly significant increase of pyruvate. Per increase of vMg by $0.1 \mathrm{mmol} / \mathrm{l}$ a significant increase of pyruvate by 0.06 $\mathrm{mg} / \mathrm{dl}(\mathrm{p}=0.002)$ was calculated (Figure 2a) as well as a highly significant decrease of the lactate-pyruvate ratio (per increase of $\mathrm{vMg}$ by $0.1 \mathrm{mmol} / \mathrm{l}$ a decrease of the lactate-pyruvate ratio by $90.9 \mathrm{p}=0.013$ ) (Figure 2b). This significant improvement of pyruvate (per increase of pyruvate by $0.1 \mathrm{mg} / \mathrm{dl}$ ) calculates a decrease of CK by $89.39 \mathrm{U} / \mathrm{l}, \mathrm{p}=0.018$ (Figure 2c). At the same time, the lactate-pyruvate ratio decreases. With the decrease of lactate-pyruvate ratio by 10 . a highly significant decrease of creatine kinase by $25.45 \mathrm{U} / \mathrm{l}(\mathrm{p}=0.008)$ is observed simultaneously (Figure 2d). Despite highly significant improvement of serum magnesium under daily magnesium spplementation for 3 months, no correlation to mitochondrial parameters (pyruvate, lactate, cellular ATP) or muscle metabolism parameter (creatine kinase) could be detected. 


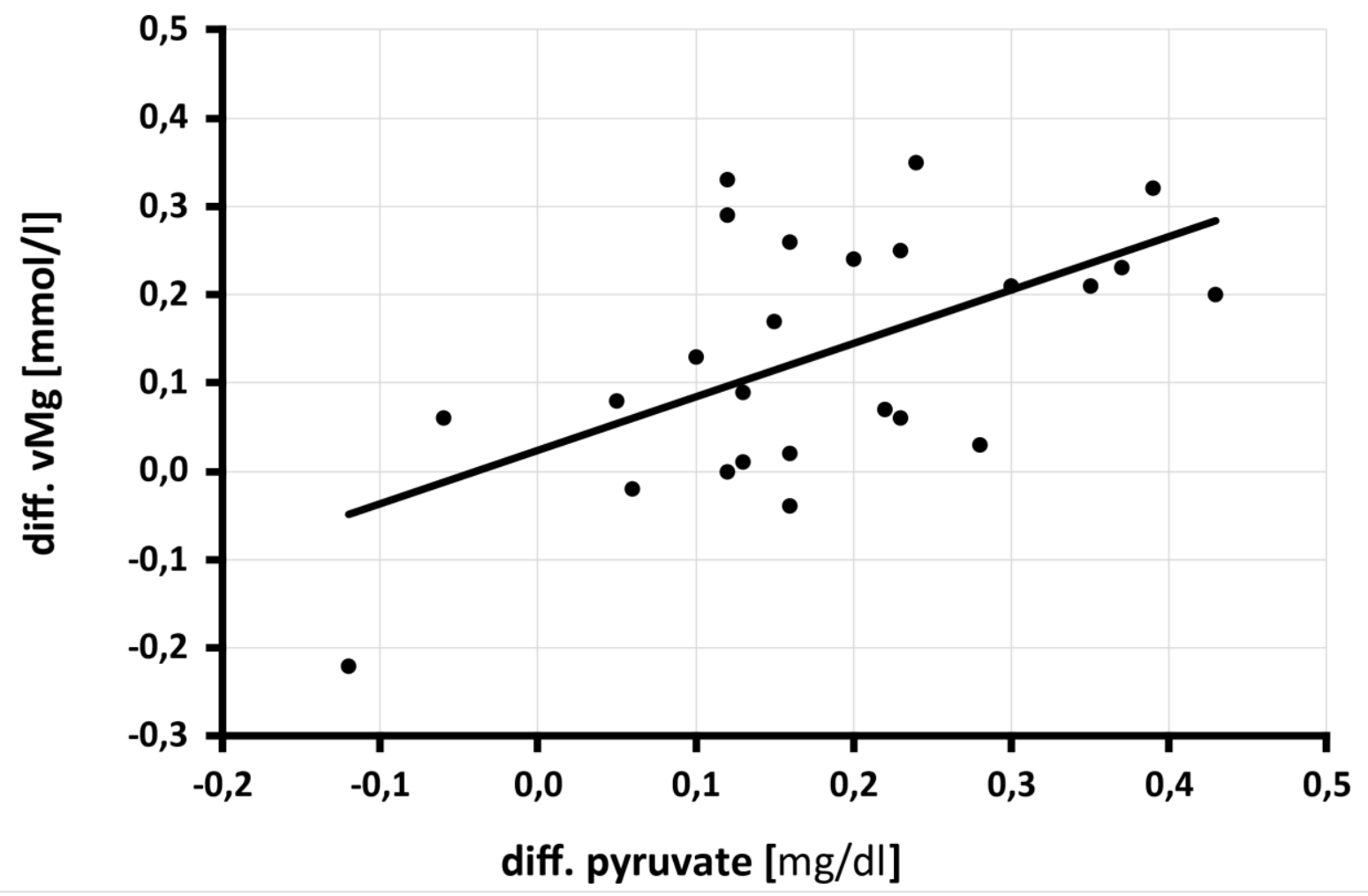

Figure 2a: Relationship between the change in pyruvate $[\mathrm{mg} / \mathrm{dl}]$ after 3 months of magnesium supplementation and the change in whole blood magnesium [mmol/1] in 25 athletes, $(r S P=0.414 . y=0.604 x+0.024-p=0.002)$.

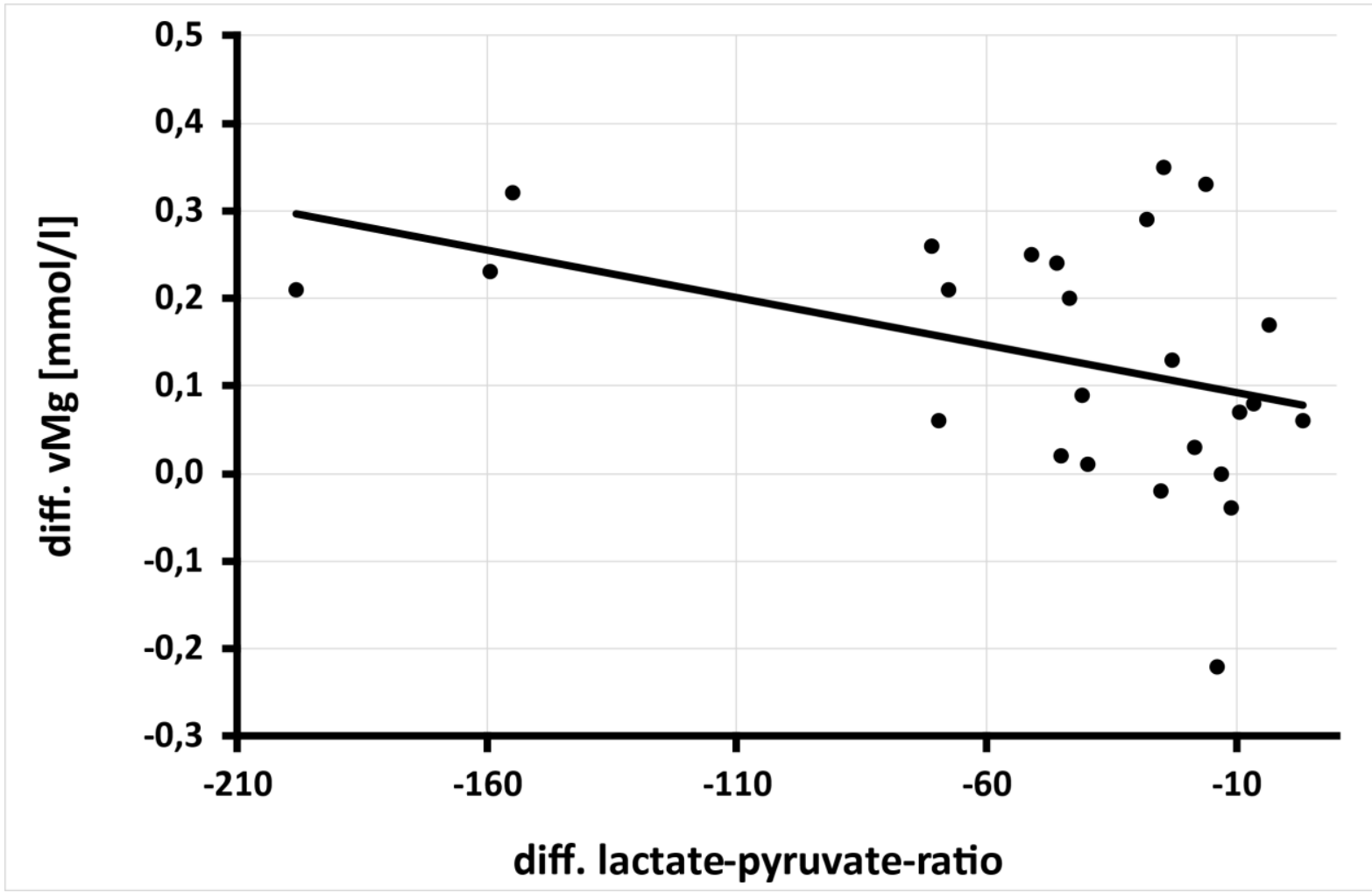

Figure 2b: Relationship between the change in lactate-pyruvate ratio [ratio] after 3 months of magnesium supplementation and the change in whole blood magnesium [mmol/1] in 25 athletes, $(\mathrm{rSP}=0.443 . \mathrm{y}=-0.0011 \mathrm{x}+0.0823-\mathrm{p}=0.013)$. 


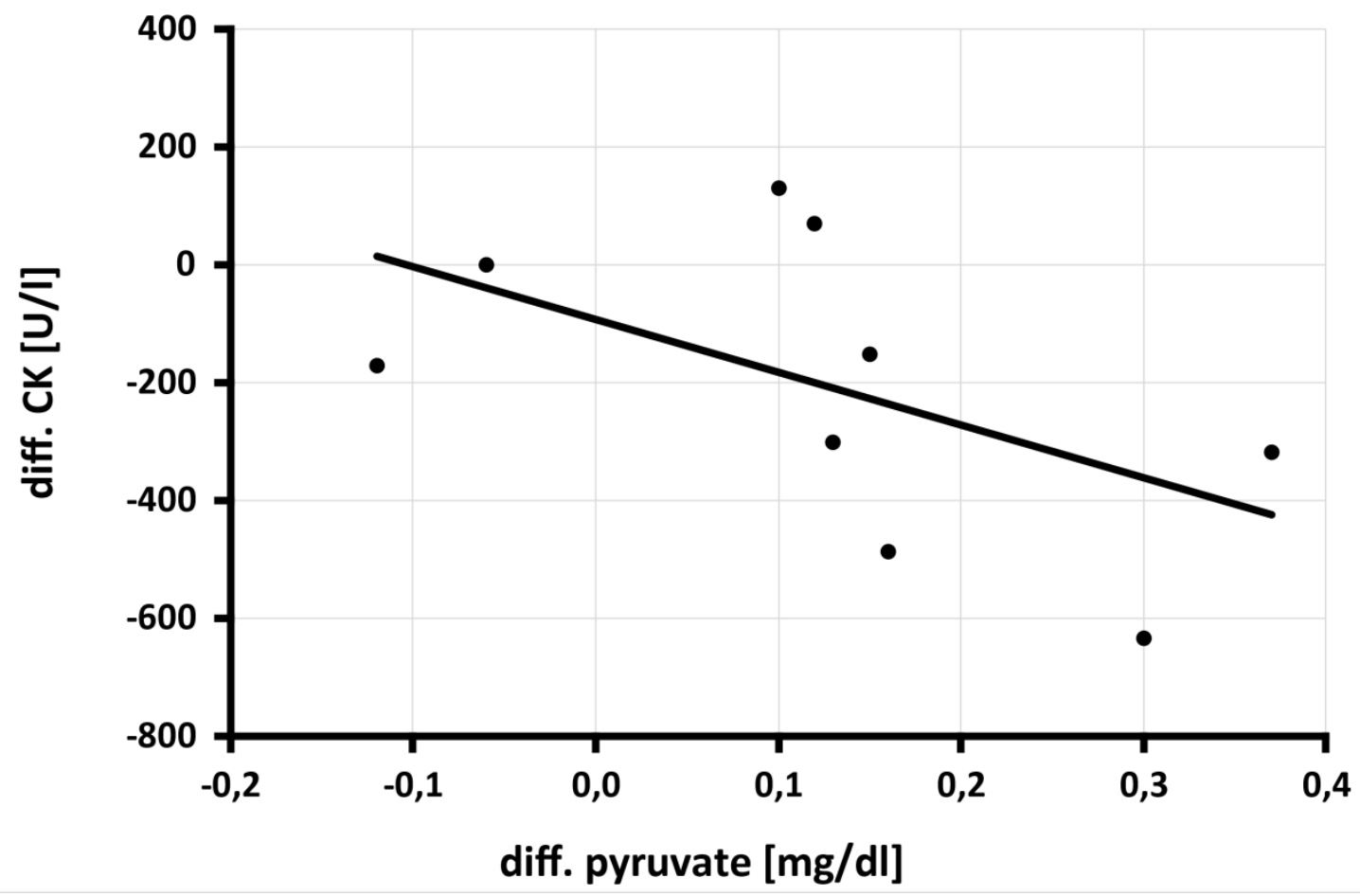

Figure 2c: Relationship between the change in pyruvate $[\mathrm{mg} / \mathrm{dl}]$ after 3 months of magnesium supplementation and creatine kinase $(\mathrm{CK})[\mathrm{U} / \mathrm{l}]$ in 9 athletes, $(\mathrm{rSP}=0.700 . \mathrm{y}=-893.94 \mathrm{x}-91.997-\mathrm{p}=0.018)$.

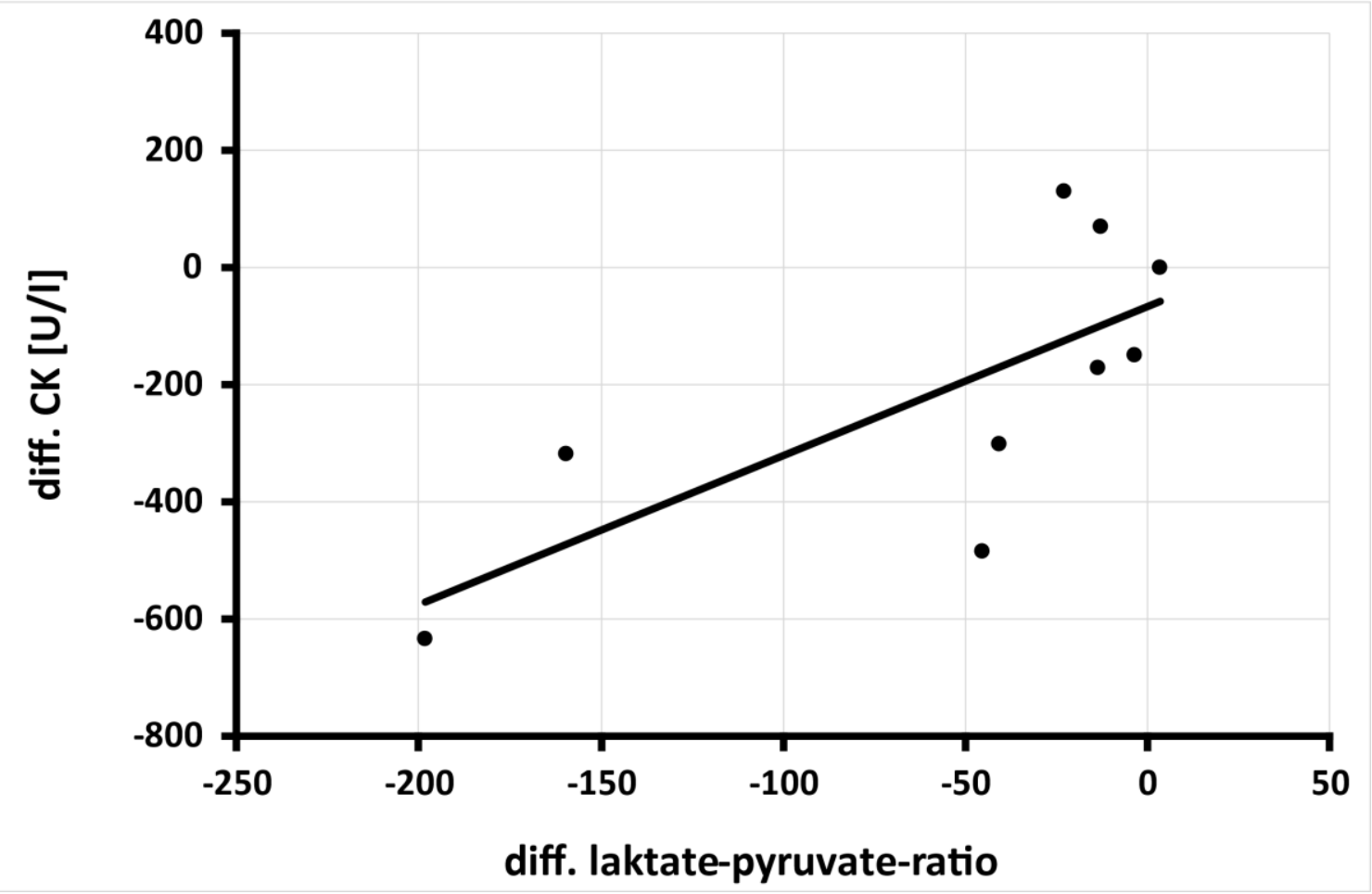

Figure 2d: Relation between the change in laktate-pyruvate-ratio after 3-months of magnesium supplementation and creatine kinase $(\mathrm{CK})[\mathrm{U} / \mathrm{l}]$ in 9 athletes, $\left(\mathrm{r}_{\mathrm{SP}}=0.767 . \mathrm{y}=2.5452 \mathrm{x}-66.684-\mathrm{p}=0.008\right)$.

\section{Discussion}

Our results show that in elite athletes, regardless of the sport, whole blood magnesium $(\mathrm{vMg})$ deficiency $(<1.29$ $\mathrm{mmol} / \mathrm{l})$ is detectable in $27.1 \%$ of cases and finds confirmation by Pollock et al [26] [22\% of 192 athletes had vMg deficiency]. The average vMg level of the athletes in our study of $1.37 \pm 0.15 \mathrm{mmol} / \mathrm{l}$ is also confirmed in the literature as 1.30 - $1.34 \mathrm{mmol} / \mathrm{l}$ (Casoni et al. [23]: $1.30 \pm 0.16 \mathrm{mmol} / \mathrm{l}(\mathrm{N}=41)$, Pollock et al. [26]: $1.34 \pm 0.14 \mathrm{mmol} / \mathrm{l}(\mathrm{N}=192)$, Fogelholm et al. [27]: $1.31 \pm 0.39 \mathrm{mmol} / \mathrm{l}(\mathrm{N}=114)$ ], whereas in our study female athletes are significantly worse supplied with vMg than male athletes $(1.33 \pm 0.11 \mathrm{mmol} / \mathrm{l}$ vs $1.41 \pm 0.13 \mathrm{mmol} / \mathrm{l}$, $\mathrm{p}=0.024)$. This is also confirmed by the study of Pollock et al [26] [female $1.33 \pm 0.06 \mathrm{mmol} / \mathrm{l}$ vs male $1.38 \pm 0.04 \mathrm{mmol} / \mathrm{l}$, p $<0.05]$. In this study [26], athletes with muscle tendon injury vs athletes without muscle tendon injury history have significantly worse vMg levels $(1.31 \pm 0.07 \mathrm{mmol} / \mathrm{l}$ vs $1.35 \pm$ $0.05 \mathrm{mmol} / \mathrm{l}, \mathrm{p}<0.05)$. Na et al. [28] and Srebro et al. [29] demonstrated that magnesium as an antagonist of the NMDA receptor plays an important role in the development of chronic pain as magnesium deficiency leads to amplification and upregulation of NMDA signaling and thus to tendon-muscle pain in athletes [30].

Also in our therapeutic study, the mean vMg level of the athletes was $1.31 \pm 0.15 \mathrm{mmol} / \mathrm{l}$, with $\mathrm{vMg}$ deficiency $(<1.29$ $\mathrm{mmol} / \mathrm{l}$ ) detected in $40 \%$ of the athletes (10/25). Serum magnesium level $(\mathrm{sMg})$ was within the normal range in all participants $(0.78 \pm 0.06 \mathrm{mmol} / \mathrm{l})$, and no athlete was found to be $\mathrm{sMg}$ deficient $(<0.66 \mathrm{mmol} / \mathrm{l})$. Also in the literature, no $\mathrm{sMg}$ deficiency could be detected in any athlete so far: the average $\mathrm{sMg}$ level in the studies was between $0.81-0.84$ $\mathrm{mmol} / \mathrm{l}$ [Fogelholm [27]: $0.81 \pm 0.05 \mathrm{mmol} / \mathrm{l} \quad(\mathrm{N}=114)$, Molina-Lopez [31]: $0.83 \pm 0.06 \mathrm{mmol} / \mathrm{l}(\mathrm{N}=14)$, Scheidtweiler (36): $0.84 \pm 0.04 \mathrm{mmol} / \mathrm{l}(\mathrm{N}=18)]$. In our 25 competitive athletes, daily supplementation of $370 \mathrm{mg}$ magnesium oxide significantly increased both $\mathrm{sMg}$ and $\mathrm{vMg}$ levels (Figure 1 or Table 2), but only the increase in $v \mathrm{Mg}$ level resulted in a significant change in glucose utilization (pyruvate and lactate) and muscle metabolism (creatine kinase) [Figure 2a-d). Thus, 
in our substitution study, an average improvement of $0.1 \mathrm{~mol} / \mathrm{l}$ $\mathrm{vMg}$ resulted in a significant improvement of pyruvate synthesis by $0.06 \mathrm{mg} / \mathrm{dl}$ (Figure 2a), which simultaneously led to a significant decrease in tissue acidification (measured in lactate-pyruvate quotient) by 90.9 units (Figure 2b). Comparable results were observed by Cinar et al (32) who were able to achieve significantly better lactate clearance compared to the control group $(\mathrm{N}=30$. $\mathrm{p}<0.05)$ when magnesium was substituted for 4 weeks $(10 \mathrm{mg} / \mathrm{kgKG} / \mathrm{day})$. Setaro et al [22] demonstrated in their randomized control trial $(\mathrm{N}=52)$ daily magnesium substitution $(350 \mathrm{mg} / \mathrm{d}-1 / 4$ weeks vs. $500 \mathrm{mg}$ maltodextrin/d-1/4 weeks) not only a significant increase in $\mathrm{vMg}$ level but also a significant decrease in lactate production and a concomitant improvement in muscle performance (counter movement jumps).

Further placebo-controlled therapy studies with daily substitution of 100 - $350 \mathrm{mg}$ magnesium for 4 - 12 weeks show the same, significant effects (reduction of lactate production, faster recovery and increased muscle strength and training performance) [31, 33]. Also in our therapy study, daily substitution of $370 \mathrm{mg}$ magnesium oxide via improvement of glucose utilization resulted in significant improvement of muscle metabolism (CK) (Figure 2c-d) and above that also performance (Figure 5: significant improvement of velocity at the $4 \mathrm{mmol}$ lactate limit of $0.68 \mathrm{~m} / \mathrm{s}$ per $0.1 \mathrm{mmol} / 1$ magnesium in whole blood above the lower normal limit of $1.29 \mathrm{mmol} / \mathrm{l}$, $\mathrm{p}=0.0024$ ) [35]. For every $0.1 \mathrm{mg} / \mathrm{dl}$ increase in the pyruvate level under magnesium substitution, a significant reduction in creatine kinase (CK) of $89.39 \mathrm{U} / 1$ can be achieved; when tissue acidity, measured by the lactate-pyruvate ratio, is relieved by 10 units, the CK level even drops highly significantly by 25.45 U/1 (Figure 2c-d). Comparable studies are not available in the international literature. The significant improvement in glucose utilization in pyruvate appears to be due to the improved kinetics of the magnesium-dependent intracellular enzymes hexokinase and phosphofructokinase [Figure 4(1)+2], smuggeling into the mitochondrion for oxidative phosphorylation via magnesium-dependent pyruvate dehydrogenase (Fig.4-PDH) and converted to energy (ATP) via magnesium-dependent mitochondrial ATPases [Figure 4(4)-(5)-6]. Proteins and lipids can also be intramitochondrically converted to energy ATP via enhancement of magnesiumdependent carbonyltransferases and propionyl-CoA carboxylase [Figure 4-3], respectively, or used in the citrate cycle for protein synthesis. The significant improvement in $\mathrm{vMg}$ level under daily magnesium supplementation for 3 months significantly optimizes glucose utilization to pyruvate, significantly increases mitochondrial ATP production, and leads to a significant decrease in $\mathrm{CK}$ via muscle lactate unloading (significant decrease in lactate-pyruvate quotient), thus optimizing muscle metabolism (Figure 3), which leads to an improvement in performance (Figure 5) and is shown in our study to result in an absolute risk reduction in muscletendon injuries of $68 \%$.

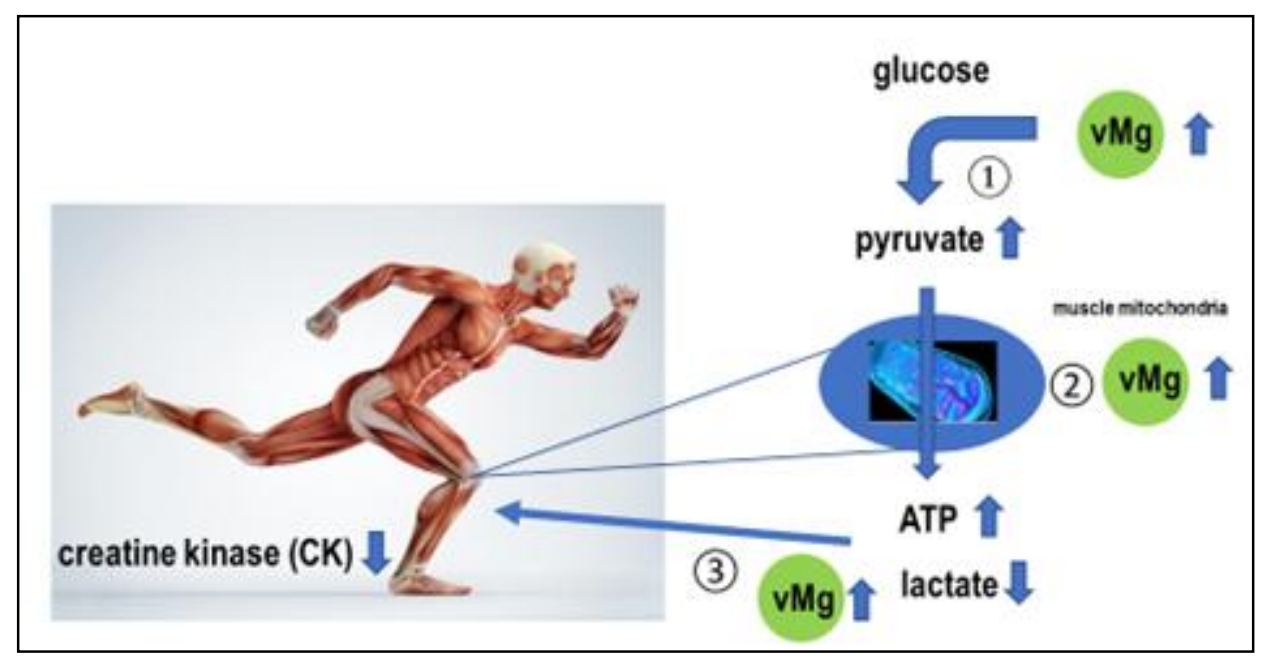

Figure 3: Procedure of mitochondrial glucose metabolism: optimization of muscle metabolism (CK) by increasing whole blood magnesium level $(\mathrm{vMg})$. (1) = Magnesium-dependent hexokinase and phosphofructokinase, (2) = Magnesium-dependent $\mathrm{Na}+/ \mathrm{K}+-$ ATPase with Mg-ATP complex V, 3 = Magnesium-dependent ADP kinase.

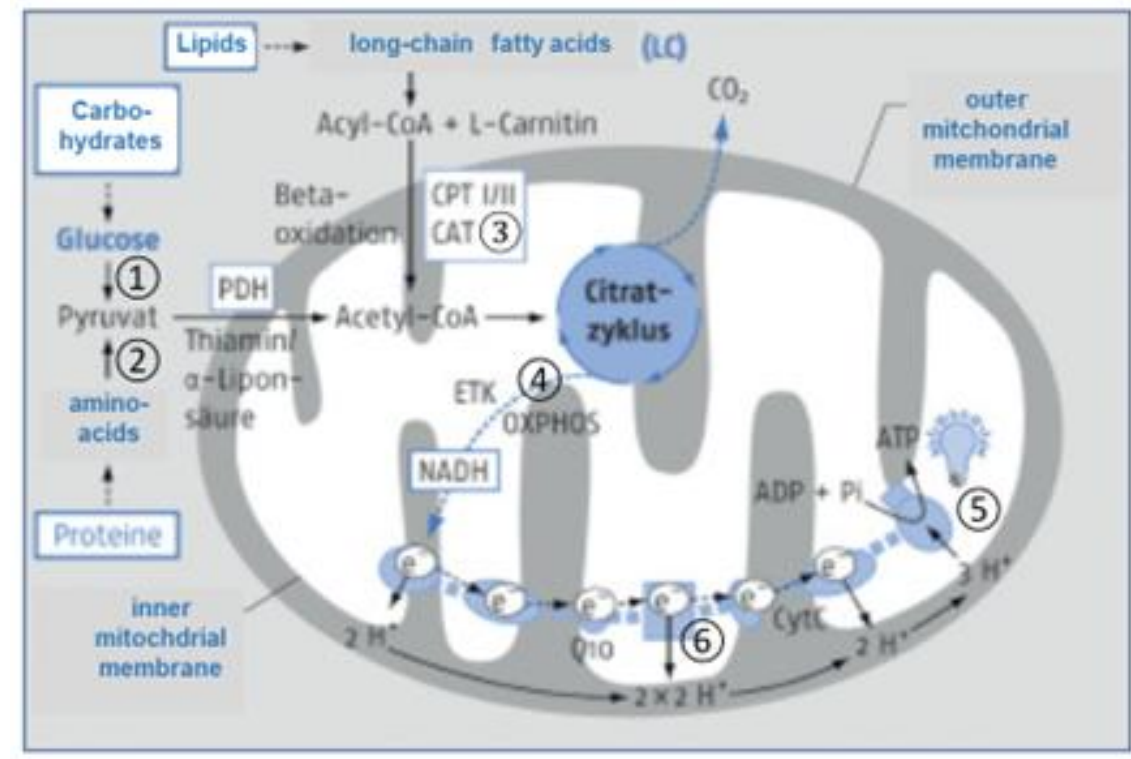

Figure 4: Magnesium-dependent mitochondrial conversion of food energy into cellular energy (ATP). PDH = pyruvate dehydrogenase (1) hexokinase-phosphofructokinase-pyruvate kinase (2) protein kinases-protein cyclases (3) carbonyltransferasepropionyl-CoA carboxylase (4) oxidative phosphorylation (5) Mg-ATP complex with Na+/K+ATPase (6) H+ or Ca++ATPase Gröber U. MedPharm Scientific Publishers, Stuttgart, 2009 [34] modified by Erpenbach et al.). 


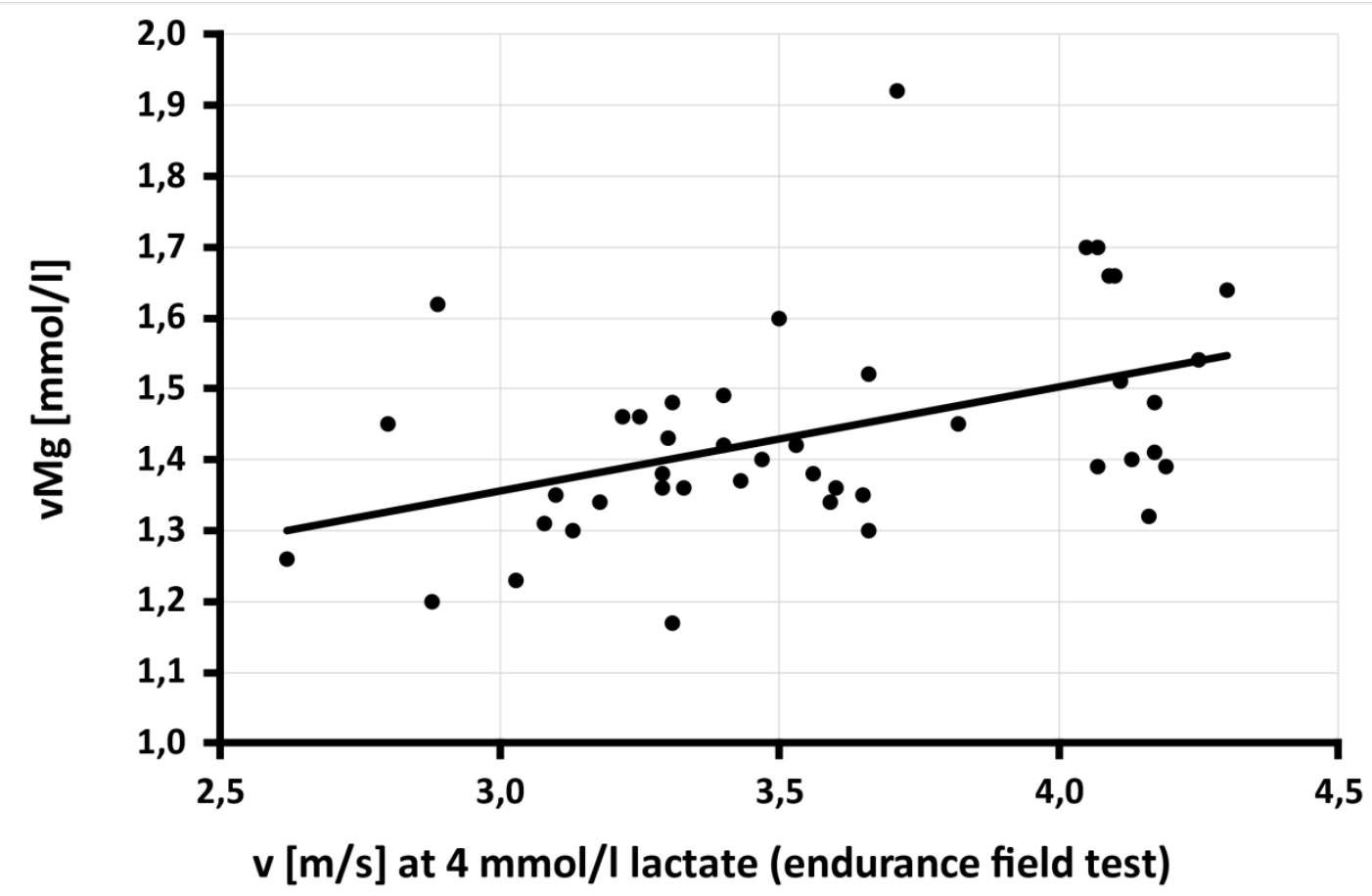

Figure 5: Relationship between speed [m/s] at $4 \mathrm{mmol} / \mathrm{l}$ lactate in the field level test and magnesium in whole blood [mmol/l] in 44 field hockey players, $(\mathrm{rP}=0.446 . \mathrm{y}=0.1469 \mathrm{x}+0.9147-\mathrm{p}=0.0024)$ [35].

\begin{tabular}{|c|c|c|c|c|c|c|c|}
\hline & $\begin{array}{c}\text { Serum- } \\
\text { Magnesium } \\
\text { (sMg) } \\
\mathbf{0 . 6 6}-\mathbf{1 . 0 7} \\
\text { mmol/l } \\
(\mathbf{n}=16) \\
\end{array}$ & $\begin{array}{c}\text { Whole Blood } \\
\text { Magnesium } \\
\text { (vMg) } \\
1.29-1.69 \\
\text { mmol/l } \\
(n=25) \\
\end{array}$ & $\begin{array}{c}\text { Pyruvate } \\
\begin{array}{c}0.34-0.72 \\
\text { mg/dl } \\
(n=25)\end{array}\end{array}$ & $\begin{array}{c}\text { Lactate } \\
\begin{array}{c}4.5-19,8 \\
\mathrm{mg} / \mathrm{dl} \\
(\mathrm{n}=25)\end{array}\end{array}$ & $\begin{array}{c}\begin{array}{c}\text { Lactate- } \\
\text { pyruvate- } \\
\text { ratio }\end{array} \\
\quad<25 \\
(\mathbf{n}=25) \\
\end{array}$ & $\begin{array}{c}\text { ATP } \\
\text { 95-100\%T- } \\
\text { Zellen } \\
(\mathbf{n}=25)\end{array}$ & $\begin{array}{c}\text { CK } \\
\begin{array}{c}30-200 \mathrm{U} / \mathrm{I} \\
(\mathrm{n}=8)\end{array}\end{array}$ \\
\hline Pre-therapy & $\begin{array}{c}0.78 \\
\pm 0.06\end{array}$ & $\begin{array}{c}1.31 \\
\pm 0.15\end{array}$ & $\begin{array}{c}0.21 \\
\pm 0.12\end{array}$ & $\begin{array}{c}10.62 \\
\pm 3.50\end{array}$ & $\begin{array}{c}70 \\
\pm 53\end{array}$ & $\begin{array}{c}90.6 \\
\pm 10.1\end{array}$ & $\begin{array}{c}457.38 \\
\pm 316.06\end{array}$ \\
\hline Post-therapy & $\begin{array}{c}0.93 \\
\pm 0.05\end{array}$ & $\begin{array}{c}1.45 \\
\pm 0.09\end{array}$ & $\begin{array}{c}0.39 \\
\pm 0.10\end{array}$ & $\begin{array}{c}8,08 \\
\pm 2.09\end{array}$ & $\begin{array}{c}23 \\
\pm 12\end{array}$ & $\begin{array}{r}99,1 \\
\pm 1.2\end{array}$ & $\begin{array}{c}304.50 \\
\pm 168,56\end{array}$ \\
\hline Significance & $\mathrm{p}<0.00025$ & $\mathrm{p}<0.00025$ & $\mathrm{p}<0.00025$ & $\mathrm{p}=0.001$ & $\mathrm{p}<0.00025$ & $\mathrm{p}<0.00025$ & $\mathrm{p}=0.036$ \\
\hline
\end{tabular}

Table 3: Values before and after 3 months of supplementation with $370 \mathrm{mg}$ magnesium oxide.

\section{Conclusion}

Elite athletes are marginally supplied with magnesium in blood serum, but deficiently with whole blood magnesium. Women experience a significantly lower level of vMg than male athletes. Further placebo-controlled randomized studies to a longer period of at least one competition season must show whether these significant magnesium-dependent intracellular and mitochondrial parameter changes lead to a sustainable prevention of muscular injuries and an increase in performance in strength and endurance.

\section{Declaration}

I, Klaus Erpenbach - first author, hereby declare that this original article has not been offered for publication or published in any other journal.

\section{References}

1. Rodriguez NR; DiMarco NM, Langley S (2009) American College of Sports Medicine position stand. Nutrition and athletic performance. Med Sci Sports Exerc 41: 709-731.

2. Kreider RB, Wilborn CD, Taylor L, Campbell B, Almada $\mathrm{AL}$, et al. (2010) ISSN exercise \& sport nutrition review: research \& recommendations. J Int Soc Sports Nutr 7: 143.

3. Walsh NP, Gleeson M, Shephard RJ, Gleeson M, Woods
JA, et al. (2011) Position statement. Part one: immunefunction and exercise. Exerc Immunol Rev 17: 663.

4. Gleeson M, Pyne DB (2016) Respiratory inflammation and infections in high-performanceathletes. Immunol Cell Biol 94: 124-131.

5. Junge A, Engebretsen L, Mountjoy ML, Alonso JM, Renström PAFSH, et al. (2009) Sports injuries during the SummerOlympic Games 2008. Am J Sports Med2009 37: 2165-2172.

6. Engebretsen L, Steffen K, Alonso JM, Aubry M, Dvorak $\mathrm{J}$, et al. (2010) Sports injuries and illnesses during theWinter Olympic Games 2010. Br J Sports Med 44: 772-780.

7. Gröber U, Schmidt J, Kisters K (2015) Magnesium in Prevention and Therapy. Nutrients 7: 8199-8226.

8. Newhouse IJ, Finstad EW (2000) The effects of magnesium supplementation on exercise performance. Clin J Sport Med 10: 195-200.

9. Crosby V, Wilcock A, Mrcp D (2000) The safety and efficacy of a single dose (500 $\mathrm{mg}$ or $1 \mathrm{~g}$ ) of intravenous magnesiumsulfate in neuropathic pain poorly responsive to strong opioidanalgesics in patients with cancer. J Pain Symptom Manage 19: 35-39.

10. Nielsen FH, Lukaski HC (2006) Update on the relationship between magnesium and exercise. Magnes Res 19: 180-189.

11. Zhang Y, Xun P, Wang R, Mao L, He K (2017) Can MagnesiumEnhance Exercise Performance? Nutrients. 9: 
28.

12. Santos DA, Matias CN, Monteiro CP, Silva AM, Rocha PM, et al. (2011) Magnesium intake is associated with strength per-formance in elite basketball, handball and volleyball players. Magnes Res 24: 215-219.

13. Musso CG (2009) Magnesium metabolism in health and disease.Int Urol Nephrol 41: 357-362.

14. Rude RK, Gruber HE, Wei LY, Frausto A, Mills BG (2003) Magnesium deficiency: effect on bone and mineral metabolism in the mouse. Calcif Tissue Int 72: 32-41.

15. Rude RK, Gruber HE, Norton HJ, Wei LY, Frausto A, et al. (2006) Reduction of dietary magnesium by only $50 \%$ in the rat disruptsbone and mineral metabolism. Osteoporos Int 17: 1022-1032.

16. Orchard TS, Larson JC, Alghothani N, Bout-Tabaku S, CauleyJA, et al. (2014) Magnesium intake, bone mineral density, and fractures: resultsfrom the Women's Health Initiative Observational Study. Am JClin Nutr 99: 926933.

17. Farsinejad-Marj M, Saneei P, Esmaillzadeh A (2016) Dietary magne-sium intake, bone mineral density and risk of fracture: a system-atic review and meta-analysis. Osteoporos Int 27: 1389-1399.

18. Lukaski HC (2004) Vitamin and mineral status: effects on physical performance. Nutrition 20: 632-644.

19. Hermes Sales C, Azevedo Nascimento D, Queiroz Medeiros AC, Costa Lima K, Campos Pedrosa LF, et al. (2014) There is chronic latent magnesium deficiency in apparently healthy university students. Nutr Hosp 30: 200-2004.

20. Brilla LR, Haley TF (1992) Effect of magnesium supplementation onstrength training in humans. J Am Coll Nutr 11: 326-329.

21. Kass LS, Poeira F (2015) The effect of acute vs chronic magnesium supplementation on exercise and recovery on resistance exercise,blood pressure and total peripheral resistance on normotensive adults. J Int Soc Sports Nutr 12: 19.

22. Setaro L, Santos-Silva PR, Nakano EY, Sales CH, Nunes $\mathrm{N}$, et al. (2014) Magnesium status and the physical performance of volleyball players: effects of magnesium supplementation.J Sports Sci 32: 438-445.

23. Casoni I, Guglielmini C, Graziano L, Reali MG, Mazzotta D, et al. (1990) Changes of magnesium concentrations in endurance athletes. Int. J. Sports Med 11: 234-237.

24. Speich M, Pineau A, Ballereau F (2001) Minerals, trace elements and related biological variables in athletes and during physical activity. Clin Chim Acta 312: 1-11.
25. Witkowski M, Hubert J, Mazur A (2011) Methods of assessment of magnesium status in humans: a systematic review. Magnes Res 24: 163-180.

26. Pollock N, Chakraverty R, Taylor I, Killer S (2020) An 8-year Analysis of Magnesium Status in Elite International Track \& Field Athletes. J Amer Coll Nutr 39: 443-449.

27. Fogelholm M, Laakso J, Lehto J, Ruokonen I (1991) Dietary intake and indicators of magnesium and zinc status in male athletes. Nutr Res 11: 1111-1118.

28. Na H-S, Ryu J-H, Do S-H (2011) The role of magnesium in pain. In: Vink R, Nechifor M, editors. Magnesium in the central nervous system. Adelaide (AU): University of Adelaide Press.

29. Srebro D, Vuckovic S, Milovanovic A, Kosutic J, Vujovic KS, et al. (2017) Magnesium in pain research: state of the art. CurrMed Chem 24: 424-434.

30. Schizas N, Lian $\emptyset$, Frihagen F, Engebretsen L, Bahr R, et al. (2009) Coexistence of up-regulated NMDA receptor 1 and glutamate on nerves, vessels and transformed tenocytes in tendinopathy. Scand J Med Sci Sports 20: 208-215.

31. Molina-Lopez J, Milona JM, Chirosa LJ, Florea D, Saez L, et al. (2012) Association between erythrocyte concentrations of magnesium and zinc in highperformance handball players after dietary magnesium supplementation. Magnesium Research 25: 79-88.

32. Cinar V, Nizamlioglu M, Mogulkoc R (2006) The effect of magnesium supplementation on lactate levels of sportsmen and sedanter. Acta Physiol Hungar 93: 137144.

33. Veronese N, Berton L, Carraro S, Bolzetta F, de Rui M, et al. (2014) Effect of oral magnesium supplementation on physical performance in healthy elderly women involved in a weekly exercise program: a randomized controlled trial. Am. J. Clin. Nutr 100: 974-981.

34. Gröber U (2009) Micronutrients. Metabolic Tuning Prevention - Therapy. Med Pharm Scientific Publishers, Stuttgart.

35. Mücke S (2009) Does the level of whole blood Magnesium has an effect on speed in lactateperformance-test?.

36. Scheidtweiler CE, Schmid A, Mücke S, Baum M, Liesen H (1996) Mineral concentration in blood compartments before and after repeated intensive physical exercise during a training camp. Int J Sports Med 17: 542.

Citation: Erpenbach K, Erpenbach MC, Mayer W, Hoffmann U, Mücke S (2021) Cellular Magnesium Level and Magnesium Supplementation in Elite Sports: Effect on Mitochondrial Function (ATP), Lactate-Pyruvate- and Muscle-Metabolism (CK). Adv Ortho and Sprts Med: AOASM-142. 